第 23 回日本臨床モニター学会シンポジウム 日臨麻会誌 Vol.33 No.1, $156 \sim 160,2013$

術後呼吸合併症と呼吸モニタリング

残存筋弛緩による呼吸抑制について

鈴木孝浩* 葛西美貴* 山本悠介* 野本聡美* 見市光寿* 小川節郎*

[要旨] 深呼吸ができない, 手を強く握れないといった明らかな筋弛緩状態が見逃されることはま れであろう. 臨床上問題なのは認識されにくい軽度(四連反応比 $0.7 〜 0.9$ ) の残存筋弛緩であり, これにより抜管後に上気道閉塞が生じ得る. 残存筋弛緩による呼吸抑制を確実に回避するには, 筋 弛緩状態を測定し, それに見合った至適量のスガマデクスを投与すること, 最終的に四連反応比の 回復を確認することが重要となる.

キーワード : 母指内転筋, 上気道, ロクロニウム, ネオスチグミン, スガマデクス

\section{I 残存筋弛緩とは?}

麻酔からの覚醒時に深呼吸ができない，頭部挙上 が5秒間持続できない, 手を強く握っていられない などの症状があり, 鎮静薬, 鎮痛薬や患者病態の影 響を除外できれば，これが残存筋弛緩に起因してい ると考えて間違いはない。このような誰にでもわか る重度の残存筋弛緩は, 筋弛緩回復薬の使用につな がるため, 臨床上まったく問題にはならない. 問題 となるのは上記の臨床的テストをクリアした結果, 客観的筋弛緩モニタリングがなされず，かつ筋弛緩 が拮抗されない症例である。つまり臨床症状では評 価できず，あくまで客観的モニタリングでしか検出 できない軽度の残存筋弛緩が問題なのである。たと えスガマデクスを用いたとしても，筋弛緩モニタリ ングを施行しなければ至適量を決定できず，実際に 本薬使用後でも筋弛緩効果の残存するケースが $4 \%$ 程度確認されている ${ }^{1)}$. 残存筋弛緩を回避するには,

*日本大学医学部麻酔科学系麻酔科学分野
現在のところ客観的モニタリングに頼らざるを得 ず，尺骨神経四連刺激 (train-of-four：TOF) 時の母 指内転筋における TOF 比 $>0.9$ を確保する必要があ $3^{2), 3)}$. しかし厳密にはこの TOF 比 $>0.9$ という值 は力感知式筋弛緩モニター (mechanomyography : $\mathrm{MMG}$ )を用いて評価されたものであり，近年臨床 で普及している加速度感知式筋弛緩モニター (acceleromyography : AMG)にはそのまま適用できない. 筋弛緩薬投与前, MMGの場合には, TOF 刺激に 対する反応である $\mathrm{T} 1$ T 4 はすべて同じ大きさと なり，その結果 $\mathrm{TOF}$ 比 $(\mathrm{T} 4 / \mathrm{T} 1)=1.0$ となるが, AMGの場合にはその機械特性によりT1から T4に かけて漸増し, TOF 比は平均で 1.1 となる ${ }^{4)}$.つま り $1.1 \times 0.9 \fallingdotseq 1.0$ が AMG 使用時の至適回復值とし て推奨される。

\section{III残存筋弛緩の評価をどの筋でする ?}

筋弛緩状態は母指内転筋で評価されることがほと

$$
\begin{array}{ll}
\text { 著者連絡先 } & \text { 鈴木孝浩 } \\
\text { T173-8610 } & \text { 東京都板橋区大谷口上町 30-1 } \\
& \text { 日本大学医学部麻酔科学系麻酔科学分野 }
\end{array}
$$




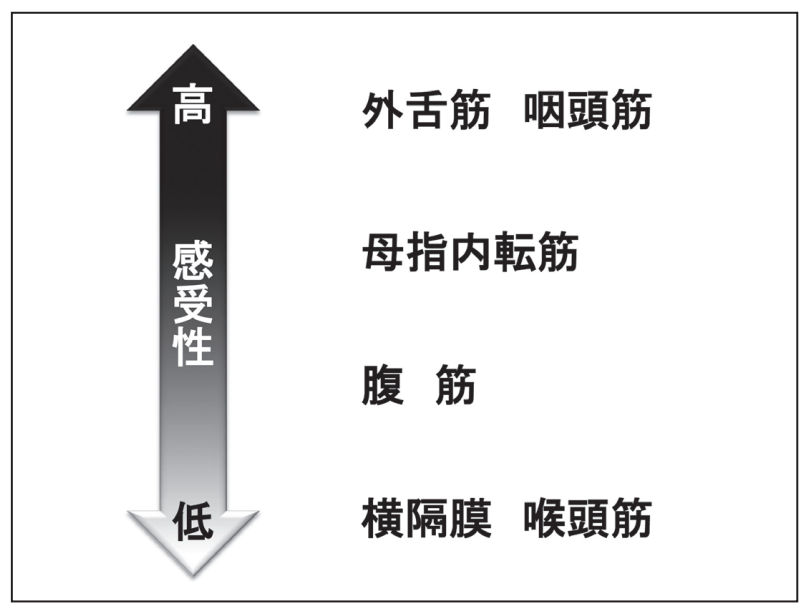

図1 筋弛緩薬への筋の感受性差

んどである。これは筋収縮反応の大きさ，モニタリ ングの容易さと非脱分極性筋弛緩薬への高感受性に よる.筋の種類により筋弛緩薬への反応性は異なり, 母指内転筋は横隔膜や喉頭筋などの呼吸筋と比較し て, 非脱分極性筋弛緩薬に感受性が高く(図 1), 筋 弛緩状態からの回復が有意に遅れる。つまり母指内 転筋である程度回復していれば，その際には正常な 呼吸筋活動は保証されることになり，母指内転筋で のモニタリングの妥当性が裏付けられる。最近まで 至適回復の gold standardであったTOF比 $>0.7$ は，この筋の感受性差を考慮した結果 ${ }^{5)}$ といえよう。 この指標は1970年代に Ali らによって提唱されたも のであり, TOF 比 $>0.7$ に回復すれば横隔膜などの 呼吸筋は筋弛緩から十分に回復しており, 肺活量や 吸気圧が正常化していることを示したものである. 確かに呼吸努力が正常化していれば抜管を試みるに 值するが，この時点で抜管して本当に呼吸抑制のリ スクはないのであろうか？ TOF 比が 0.7 から新指 標の 0.9 (AMGでは 1.0)の間の軽度筋弛緩の状態で は，どんな弊害があるであろうか？この場合，母 指内転筋よりもさらに筋弛緩薬に感受性の高い筋, 具体的には呼吸にかかわる上気道筋の筋弛緩状態へ の配慮が重要となる。しかし臨床麻酔においては上 気道筋の筋弛緩状態を客観的に評価するのは非常に
困難であるため，あくまで母指内転筋の状態から推 察するしかない.

\section{III 軽度の残存筋弛緩でも生じる呼吸抑制とは？}

母指内転筋で軽度の筋弛緩状態であっても，上気 道を拡大させる外舌筋，舌骨上筋，咽頭筋収縮機能 は有意に抑制される。例えば舌を前方に引き出すオ トガイ舌筋が機能しないと, 舌根沈下が生じ上気道 閉塞が生じる.母指で TOF 比 0.8 に回復していても, 上気道径はいまだ基準值に達しない(図2 $)^{6}$. 。 り横隔膜がフル稼働しても, 上気道が閉塞していれ ば十分な吸気量が得られず，すぐに低酸素血症，高 二酸化炭素血症を招くことになる。

さらに TOF 比 0.7 では筋弛緩薬の頝動脈体化学受 容体への作用のため, 低酸素により誘発されるはず の呼吸促進反応が抑制されている $(\text { 図3) })^{2)}$ た，低 酸素血症発症時にそれを改善させる安全機構も働か ないことになる。つまり軽度の残存筋弛緩であって も，十分に呼吸抑制が生じ得るのである。

その他呼吸器に関するトラブルとして, 抜管後の 誤嚥に留意せねばならない。上部食道括約筋の安静 時張力は TOF 比< 0.8 の状態では, まだ対照值の $50 \%$ 以下と有意に低圧である $\left(\right.$ 図 4) ${ }^{3)}$ ため, 胃液の 咽頭への逆流を生じやすくなる。また嚥下する際, 通常は上部食道括約筋の弛緩後, 十分な時間をおい てから物を送り込むために咽頭括約筋が収縮し始め るが，部分遮断時にはそのタイミングが有意に短縮 するため，喉頭への誤流入が認められるようにな る ${ }^{3)}$.

\section{IV どの程度の呼吸抑制が生じるか？}

ある前向き臨床研究の結果 ${ }^{7)}$ を紹介する. 手術中 の筋弛緩維持にロクロニウムを使用し, 手術終了後, 尺骨神経刺激による視覚的な TOF カウントが 3 以 上に回復した時点でネオスチグミン $50 \mu \mathrm{g} / \mathrm{kg}$ を投 与し, 頭部挙上, 握力, 安定した自発呼吸の回復を 観察した後に抜管した。その後PACU 搬送時の残 


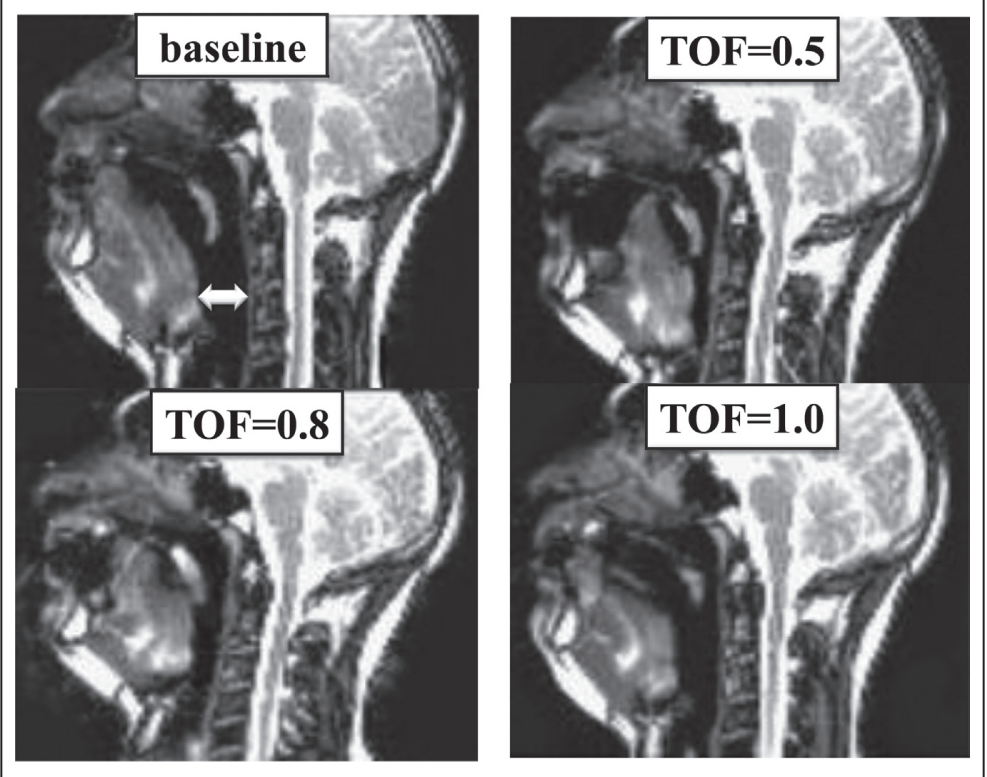

図2 残存筋弛緩と上気道径

TOF 比が 1.0 に回復しないと舌根沈下により上気道径は正常化しな い.

〔文献 6)より引用・改変]

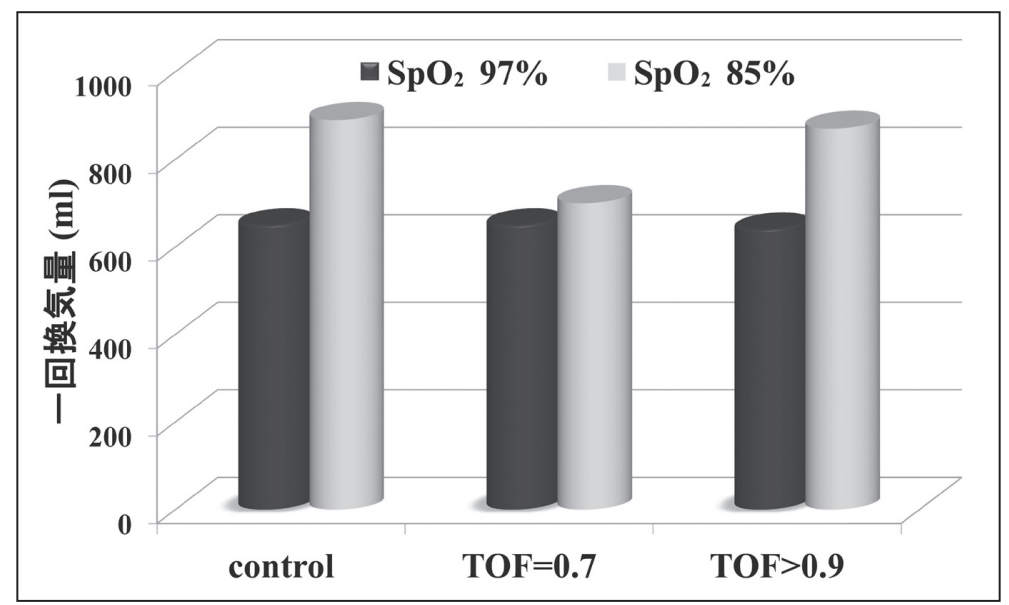

図3 低酸素刺激による一回換気量変化

経皮酸素飽和度を $85 \%$ にすると, 通常は一回換気量が増加する。し かし軽度残存筋弛緩の状態ではその増加が認められない. TOF > 0.9 になればこの代償機能は回復する。〔文献2)より引用・改変〕

存筋弛緩率は TOF 比 $0.7 \sim 0.9$ と軽度筋驰緩状態が $16.7 \%$, TOF 比 $<0.7$ と重篤な状態は $13.3 \%$ に上 った。酸素吸入しながらPACUに移送したが，そ の間の $\mathrm{SpO}_{2}$ が 90 〜 93\%に低下した率は $18.9 \%, 90$ \%未満に低下した率は $21.1 \%$ で，約 $11 \%$ の患者では
移送中にエアウェイなどを要した。もちろん対照と なる $\mathrm{AMG}$ 使用群では抜管時の TOF 比を確認して いるため, PACU移送中に $\mathrm{SpO}_{2}<90 \%$ といった重 篤な低酸素例は認められなかった。この結果からも わかるように，残存筋弛緩による呼吸抑制を予防す 


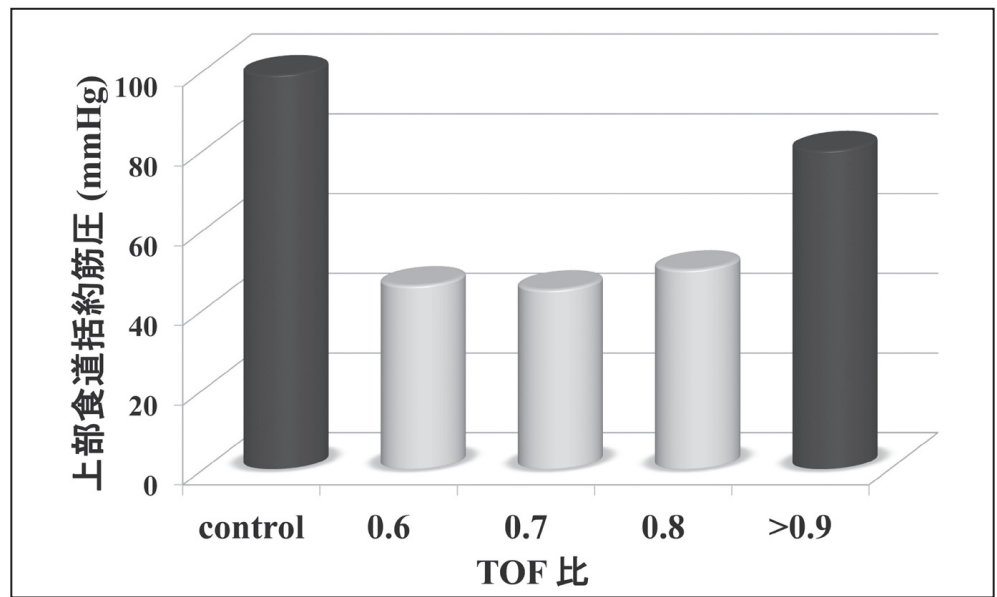

図4 軽度筋弛緩と上部食道括約筋圧の変化

TOF 比 $>0.9$ に回復しないと上部食道括約筋圧は正常化しない。つ まり軽度筋弛緩状態では誤嚥の可能性が高い.

〔文献3)より引用・改変〕

るにはリバースすることが大事なのではなく，十分 に筋弛緩から回復したことを最終的に客観視するこ とが必要なのである.

\section{$\mathrm{V}$ 念のためのネオスチグミンは安全？}

抗コリンエステラーゼは神経筋接合部内でアセチ ルコリン量を増加させ，非脱分極性筋弛緩薬との競 合作用を高めるという間接的な拮抗作用を発揮す る。筋弛緩からの回復が十分な際にネオスチグミン が投与されると，この増加したアセチルコリンが逆 に神経筋遮断，いわゆる脱感作性ブロックを誘発し てしまう恐れがある ${ }^{8)}$. AMGにてTOF $>1.0$ が得 られている場合には，ネオスチグミンの投与は避け るべきであり，それでもなお術後の再クラーレ化を 予防すべく，さらに筋弛緩薬の受容体占拠率を減少 させたいと考える場合にはスガマデクスの使用が勧 められる。

\section{まとめ}

軽度の残存筋弛緩でも上気道閉塞による呼吸障害 を起こし得る。これにより呼吸性アシドーシスを合 併した場合, 再クラーレ化を生ずる可能性もあるた
め軽度であっても残存筋弛緩を見逃すことがあって はならない.

\section{参考文献}

1) Takagi S, Ozaki M, Kotake Y, et al. : Sugammadex has a lower incidence of postoperative residual curarization than neostigmine. American Society of Anesthesiology, Chicago, Illinois, 2011

2) Eriksson LI, Lennmarken C, Wyon N, et al. : Attenuated ventilatory response to hypoxaemia at vecuroniuminduced partial neuromuscular block. Acta Anaesthesiol Scand $36: 710-715,1992$

3) Eriksson LI, Sundman E, Olsson R, et al. : Functional assessment of the pharynx at rest and during swallowing in partially paralyzed humans : simultaneous videomanometry and mechanomyography of awake human volunteers. Anesthesiology 87 : 1035-1043, 1997

4) Suzuki T, Fukano N, Kitajima O, et al. : Normalization of acceleromyographic train-of-four ratio by baseline value for detecting residual neuromuscular block. Br J Anaesth $96:$ 44-47, 2006

5) Ali HH, Wilson RS, Savarese JJ, et al. : The effect of tubocurarine on indirectly elicited train-of-four muscle response and respiratory measurements in humans. Br J Anaesth $47: 570-574,1975$

6) Eikermann M, Vogt FM, Herbstreit F, et al. : The predisposition to inspiratory upper airway collapse during 
partial neuromuscular blockade. Am J Respir Crit Care Med 175 : 9-15, 2007

7) Murphy GS, Szokol JW, Marymont JH, et al. : Intraoperative acceleromyographic monitoring reduces the risk of residual neuromuscular blockade and adverse respiratory events in the postanesthesia care unit. Anesthesiology 109:389-398, 2008

8）北島治, 鈴木孝浩, 深野直子ほか：ネオスチグミンに よる神経筋刺激伝達抑制に関する検討. 麻酔 58 : 410415,2009

\title{
Respiratory Depression Caused by Residual Neuromuscular Block
}

\author{
Takahiro SUZUKI, Miki KASAI, Yusuke YAMAMOTO, \\ Satomi NOMOTO, Mitsuhisa MIICHI, Setsuro OGAWA \\ Department of Anesthesiology, Nihon University School of Medicine
}

Clinical symptoms suggesting severe residual neuromuscular block such as diminished ability to breathe deeply and hold examiner's hands tight may occasionally be missed by anesthesiologists before tracheal extubation. Instead, unrecognized mild residual neuromuscular block defined as trainof-four(TOF) ratios between 0.7 and 0.9 may be clinically important and potentially cause upper airway obstruction. To prevent respiratory depression caused by residual neuromuscular block, it is essential to objectively evaluate the depth of neuromuscular block, administer an optimum dose of sugammadex and finally verify adequate recovery to a TOF ratio of 0.9 .

Key Words : Adductor pollicis muscle, Upper airway, Rocuronium, Neostigmine, Sugammadex

The Journal of Japan Society for Clinical Anesthesia Vol.33 No.1, 2013 